the reader does not foresee the conclusions Rozman is driving at, it is not always apparent why he concentrates on various details.

I am afraid this book might be ignored by Russian historians because of the general theoretical nature of the model and by urban sociologists because they might wrongly assume the results are relevant only to Russia. Such an outcome would be unfortunate, because this book has a great deal to offer students both of Russia and of economic development.

Barbara A. Anderson

Brown University

\title{
IMPERIAL RUSSIA IN FRONTIER AMERICA: THE CHANGING GEOG- . RAPHY OF SUPPLY OF RUSSIAN AMERICA, 1784-1867. By James $R$. Gibson. Mikos Pinther, cartographer. New York: Oxford University Press, 1976. xiv, 256 pp. Illus. Maps. $\$ 10.00$, cloth. $\$ 6.00$, paper.
}

The lure of Russian America--Russia's only overseas colony, comprising Alaska, the Aleutian, Pribilof, Commander, and Kurile Islands and impermanent subsidiary developments in Hawaii and California-was fur. The quickly depleted sea otter, primarily, and the more numerous, less valuable, and more slowly reduced fur seal were the inducement for numerous licensed expeditions to, and chartered company exploitation of, the marine fur resources of the northern Pacific after 1740. Distance from the homeland, as western Pacific rookeries were exterminated, made permanent settlement essential and, in view of climatic and manpower limitations on agriculture, regular imported food supplies mandatory.

Gibson's book is a study of the costly, uncertain, and ultimately unresolved search for a reliable, inexpensive food base for the colonies. The Russian-America Company, the designated controlling operation in 1799, originally supplied its "counters" (colonies) from Siberia-by boat down the Lena to Yakutsk and by man- and horsekilling overland pack routes to the port of Okhotsk (and later Ayan). The transpacific route was later supplemented by equally costly and irregular circumnavigations from Kronstadt. Ultimately, however, it was local supply which was essential. The failure of northern agriculture and the Russian-America Company's informal and formal trade arrangements with New England and Hudson's Bay men (who simultaneously were poachers on the fur trade and subverters of controlled natives) and with Californians and Hawaiians are the substance of Imperial Russia in Frontier America. It tells little about the fur trade; it does explore in informative detail the changing patterns of trade relations, political geography, and settlement of more than one hundred years of Russia in America.

Jerome D. Fellman N

University of Illinois at Urbana-Champaign

NESSELRODE AND THE RUSSIAN RAPPROCHEMENT WITH BRITAIN, 1836-1844. By Harold N. Ingle. Berkeley: University of California Press, 1976. xii, 196 pp. $\$ 11.75$.

Russia's foreign policy in the nineteenth century was remarkably stable. Though ultimately determined by objective conditions of the nation's existence and the will of autocratic tsars, it was shaped and executed throughout most of the century by only two individuals, Count Karl Robert Nesselrode and Prince Aleksandr Mikhailovich Gorchakov. Neither has found a competent biographer, but Nesselrode, who, unlike 